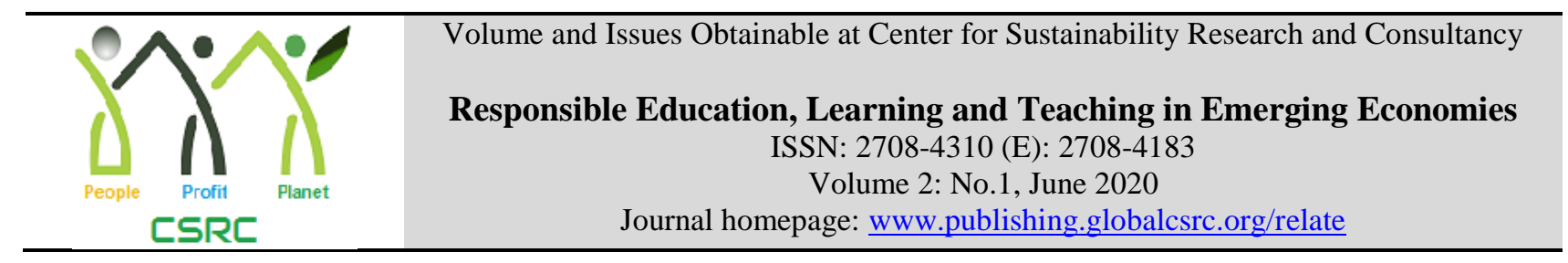

\title{
Relationship of Achievement Goal Orientation of University Teachers designation at Work Engagement and Organizational Commitment
}

\begin{tabular}{|c|c|}
\hline $\begin{array}{l}{ }^{1} \text { Assistant Professor, } \\
\text { ssistant Professor, La }\end{array}$ & $\begin{array}{l}{ }^{1} \text { Khadija Sittar, }{ }^{2} \text { Sumaira Munawar, } \\
\text { ore Leads University, Lahore, Pakistan, khadijasittar@gmail.com } \\
\text { Leads University, Lahore, Pakistan, sumairamunawar16@gmail.com }\end{array}$ \\
\hline ARTICLE DETAILS & ABSTRACT \\
\hline $\begin{array}{l}\text { History } \\
\text { Revised format: May } 2020 \\
\text { Available Online: June } 2020\end{array}$ & \multirow{3}{*}{$\begin{array}{l}\text { The study was exploring the relationship between achievement goal with } \\
\text { teachers' designation at work engagement and organizational commitment. } \\
\text { Research adopted quantitative approach and correlation design was used. The } \\
\text { respondents of the study were selected from two districts (Lahore and } \\
\text { Faisalabad) of the Central Punjab. } 145 \text { teachers from public and private } \\
\text { universities of central Punjab were selected. Universities were selected } \\
\text { through stratified random sampling technique. Data collection was done with } \\
\text { the help of two instruments. Relationship between goal orientation, work } \\
\text { engagement and organizational commitment was explored by applying } \\
\text { Pearson r. Teachers' designation as demographic variable was taken to find } \\
\text { out significant difference by applying One-way ANOVA. Findings of the } \\
\text { study revealed that there was a moderate positive correlation between male } \\
\text { and female teachers designation. }\end{array}$} \\
\hline $\begin{array}{l}\text { Keywords } \\
\text { Achievement goal orientation, } \\
\text { Work engagement, Organizational } \\
\text { commitment. }\end{array}$ & \\
\hline $\begin{array}{l}\text { JEL Classification: } \\
I 20, I 23\end{array}$ & \\
\hline
\end{tabular}

\section{OPEN $\bigcirc$ ACCESS}

(C) 2020 The authors, under a Creative Commons AttributionNonCommercial 4.0

Corresponding author's email address: khadijasittar@gmail.com

Recommended citation: Sittar, K. \& Munawar, S. (2020). Relationship of Achievement Goal Orientation of University Teachers designation at Work Engagement and Organizational Commitment. Responsible Education, Learning and Teaching in Emerging Economies, 2(1), 23-28.

\section{Introduction}

In an individual's life goals are very crucial. The term "Goals" is basically an organization or an individual's plans or thoughts which are carried out to attain the desired results. According to Austin and Vancouver (1996), goal is the final illustration of all the activities of an individual for which he struggle. In specific conditions, the likely outcomes of an individual in response of guided actions and reactions are defined as goals which keep them devoted to their responsibilities and guide the persons to live deliberately or unintentionally. Unconscious desires or drilled objectives with a range of everlasting morale inspirations to a specific aim are also come in the category of goals (Carver \& Scheier, 1981).

Goals are actually linked with reasons, which are taken as high general, affect laden depositions that work as running of high-level function in motivation by starting desires, related to and behavioural tendency just like result accepted. Those inherent qualities are known as goal orientations.

Achievement goal theory proposed by Ames \& Ames in 1984 suggested that individuals can struggle for performance approaching and performance avoiding goals (VandeWalle, 2004) and these are referred to the trend to fretful with 
positive validation of validated behaviour of others. There is a category of individual's intention goals to mature competencies, skills or knowledge are known as learning goals. According to Dweck, 2008 in learning goals, individuals take their challenging tasks as their opportunity of learning and an initiative of learning skills. Individuals with performance orientation have their relative standards which include both their external such as colleagues, performance norms and internal factors for example, individual expectations, or previous performance levels to compare themselves (Van Yperen, 2006). VandeWalle, 2004 describe the difference between performance approaching goals and performance avoiding goals is that performance approaching goals are linked with indicating the high performance of others while performance avoiding goals just indicate the incompetence demonstration of others. According to Chughtai \& Buckley, 2010 there is a positive correlation between teacher's feedback seeking behaviour and learning goal orientation and it is the criteria while adopting learning goal orientation that positive and negative environmental cues are just consider to improve the learning skills, although not the criteria to judge the performance (VandeWalle, 2004). It was described by Butler, 2007; Schiefele \& Schaffner in 2015 that there is always a higher level of self-efficacy in the teachers who have high learning goal orientation as the part of their personality and it was also noticed that teachers with aforesaid personality are proved more supportive to their students (Butler \& Shibaz, 2008). Moreover it was proved by the socioemotional selectivity theory proposed by Carstensen in 2006 that older workers always have less future-focused goals in their personality which indicate that their motivational level to become the part of opportunities of learning is always lower.

However we are finally concluded age as backbone feature in our study to describe why entities are given to a precise goal orientation profile.

Actually, there are many studies related to positive behaviour of workers round organizational commitment, work assignation theme being used enhanced in the current years. Work engagement mention in excess of extent persons obeying the job, it is related how much there is, and what is the spirit while undertaking the job. (Bakker, \& Bal, 010). workers are united their work with expressive and reasonable functional. Emotional addition of people has capability to understand with colleagues, create expressive associations with managers. Intellectual combination describes the people with actually conscious of their goal and characters (Esen,2011).

There is a near association among organizational commitment and work appointment. Gallup organizational who is investigated this association in America originate workers who are united with work are faithful for organization related to psychological and enthusiastic and keen (Esen,2011).workers create of their organization, they also create a struggle and devoted time depent on wish, they have little bit stress, their job gratification are increase, they consume lesser medical helps, they got approvals inferior than others, they are creative and work in organization for a long period. There are some investigator related to this association among organizational promise and combination with work.

The assessment originates that work appointment speaks to a negotiating part in the link among the forerunner (work qualities, saw association bolster, saw manager support, acknowledgment and award, and equity) and appointment consequences (profession fulfillment, convincing responsibility, belief, and citizenship and behavior).Similarly, Brown and Leigh (1996) hypothetically that a area understood just like mentally dwindling and considerable representatives as a rule stimuli addition in work insertion and work of the relationship. Similarly, subjective and emotional circumstances linked of completion of workers, responsibilities and inspiration.

Hakanen (2008) boarded to check the inspiration and welfare faintness forms just like planned in the job DemandsResources (JDR) presentation and to see at the degree home resources and home needs may influence both measures over a specific time. The assessment originate occupation resources effect on future work appointment at last stimuli hierarchical duty, when compared with service requests which predict stress under a specific period that in the end quick expected forecast of future mouring. 


\section{Objectives of the study}

The study was conducted to achieve the following objectives to:

Explore the relationship of achievement goal orientation and work engagement.

Explore the relationship of achievement goal orientation and organizational commitment.

Identify the difference in achievement goal orientation of teachers with work engagement and organizational commitment on the basis of designation.

\section{Research Questions}

In this study following research questions were address.

Is there any relationship between achievement goal orientation and work engagement of teachers?

Is there any relationship achievement mastery goal orientation and organizational commitment?

Is there any difference between achievement goal orientations of teachers with work engagement and organizational commitment on the basis designation?

\section{Research Methodology}

The study was quantitative in nature and correlation research design awas used.

\section{Population}

All public and private university teachers of Central Punjab were the population of this study. There are 30 general type universities (15 public, a15 private) in Central Punjab.

\section{Table 1}

Population of the study

\begin{tabular}{ll}
\hline Type Of Universities & Total \\
\hline Public universities & 27 \\
Private universities & 24 \\
\hline
\end{tabular}

\section{Sample and sampling technique}

Sample of the study was university teachers. For sample selection stratified sampling was used. Two public and two private universities were randomly selected. Teachers were selected by using censes sampling technique according their designation (lecturer, Assistant Professor, Associate Professor, Professor).

\section{Instrumentation}

\subsection{Questioner was used for data collection.}

The researcher was used a self-developed questionnaire for data collection. The questionnaire was consisted of five point likert scales. Questionnaire was consisted achievement goal orientation, work engagement and organizational commitment.

\section{Data collection}

Researcher was visit the universities herself for data collection. Data from selected teachers from 4 general type universities ( 2 public) and ( 2 private) were collected personally by the researcher.

\section{Data Analysis}

Data were analysed by using inferential statistic and descriptive statistics. Pearson-r/ Regression was applied to examine the correlation between variables. One way ANOVA was used in order to see the significance of the difference among achievement goal orientation university teachers for "work engagement and organizational commitment" on the basis of designation.

\section{Results}

Table 1

Teachers Description on the Basis of Designation 


\begin{tabular}{cll}
\hline Lecturer & 89 & 56.0 \\
Assistant Professor & 42 & 26.4 \\
Associate Professor & 18 & 11.3 \\
$\quad$ Professor & 10 & 6.3 \\
Total & 159 & 100.0 \\
\hline
\end{tabular}

Table showed that teachers were selected on the basis of designation. It showed that $89(56 \%)$ were lecturer and $42(26.4 \%)$ assistant professor, $18(11.3 \%)$ associate professor and $10(6.3 \%)$ teacher were professor from public and private universities.

Table 2

Relationship between Work Engagement and Achievement Goal Orientation

\begin{tabular}{llll}
\hline Variables & $N$ & $r$-value & Sig. \\
\hline $\begin{array}{l}\text { Work engagement and achievement } \\
\text { goal orientation }\end{array}$ & 159 & .254 & .001 \\
\hline
\end{tabular}

Relationship between work engagement and achievement goal orientation in university teachers was explored by using Pearson r. Results show that positive weak significant relationship among work engagement and achievement goal orientation. R-value shows weak positive significant relationship $r=.254$ at $p<.05$ among two variables.

Table 3

Relationship between Organizational commitment and achievement goal orientation

\begin{tabular}{lllll}
\hline Variables & & $N$ & r-value & Sig. \\
\hline $\begin{array}{l}\text { Organizational commitment } \\
\text { achievement goal orientation }\end{array}$ & and & 159 & .354 & .001 \\
\hline
\end{tabular}

Relationship between organizational commitment and achievement goal orientation in university teachers was explored by using Pearson r. Results show that positive weak significant relationship among organizational commitment achievement goal orientation. R-value shows weak positive significant relationship $r=.354$ at $p<.05$ among two variables.

Table 4

Relationship between Organizational Commitment and Work Engagement

\begin{tabular}{lllll}
\hline Variables & & $N$ & r-value & Sig. \\
\hline $\begin{array}{l}\text { Organizational commitment } \\
\text { Work engagement }\end{array}$ & and & 159 & .554 & .001 \\
\hline
\end{tabular}

Relationship between organizational commitment and work engagement in university teachers was explored by using Pearson r. Results show that positive weak significant relationship among organizational commitment and work engagement. R-value shows weak positive significant relationship $r=.354$ at $p<.05$ among two variables.

Table 5

Difference among teachers about Achievement Goal Orientation on the basis of designation

\begin{tabular}{lccccc} 
Designation & Sum of Squares & $d f$ & Mean Square & $F$ & Sig. \\
\hline $\begin{array}{l}\text { Achievement } \\
\text { Orientation }\end{array}$ & Goal & & & & \\
& 29.317 & 30 & .977 & & \\
& & & & \\
& 101.324 & 128 & .792 & \\
& 130.642 & 158 & & \\
\hline
\end{tabular}

Table shows that one way ANOVA was used to see the difference among teachers about achievement goal orientation on the basis of designation. There was no significant difference $F(158)=1.235), p=.210$ in achievement goal 
orientation of teachers on designation "(lecturer, assistant professor, associate professor, professor)". Table 6

Difference among teachers about Work Engagement on the basis of designation

\begin{tabular}{llllll}
\hline Designation & Sum of Squares & $D f$ & Mean Square & $F$ & Sig. \\
\hline Work Engagement & 20.948 & 30 & .698 & .815 & .738 \\
& 109.693 & 128 & .857 & & \\
& 130.642 & 158 & & & \\
\hline
\end{tabular}

Table shows that one way ANOVA was used to see the difference among teachers about work engagement on the basis of designation. There was no significant difference $F(158)=.815), p=.738$ in work engagement of teachers on designation "(lecturer, assistant professor, associate professor, professor)".

Table 7

Difference among teachers about Organizational commitment on the basis of designation

\begin{tabular}{llllll}
\hline Designation & \multicolumn{3}{c}{ SS } & & \\
\hline Organizational Commitment & & & & & \\
& 27 & 1.094 & 29.532 & 1.417 & .102 \\
& & & & & \\
& 131 & .772 & 101.109 & & \\
& 158 & & 130.642 & \\
\hline
\end{tabular}

Designation wise difference between teachers regarding organizational commitment was found in this above table. Teachers having designation (lecturer, assistant professor, associate professor, professor) was found not to be significant different $F(158)=1.417 p=.102$. 


\section{References}

Austin, J. T., \& Vancouver, J. B. (1996). Goal constructs in psychology: Structure, process, and

content. Psychological Bulletin, 120(3), 338-375.

Ames, C., \& Ames, P. (1984). System of student and teacher motivation towards a definition. Journal of Educational Psychology, 76(4), 535-556.

Brown, S.P., \& Leigh, T.W., (1996). A lew look at psychological climate and its relationship to job involvement, effort, and performance. Journal of Applied Psychology, 218(81), 358-368

Bakker, B. A., \& Bal, P. M. (2010). Weekly work engagement and performance: a study among teachers. Journal of Occupational and Organizational Psychology, 83, 189-206.

Butler, R. (2007). Teachers' achievement goal orientations and associations with teachers' help seeking: Examination of a novel approach to teacher motivation. Journal of Educational Psychology, 99(2), 241-252.

Butler, R., \& Shibaz, L. (2008). Achievement goals for teaching as predictors of students' perceptions of instructional practices and students' help seeking and cheating. Learning and Instruction, 18(5), 453-467.

Carver, C. S., \& Scheier, M. F. (1981). Attention and self-regulation: a control-theory $\quad$ approach to human behavior. New York: Springer Verlag,

Carstensen, L. L. (2006). The influence of a sense of time on human development. Science, 312(5782), 1913-1915.

Chughtai, A. A., \& Buckley, F. (2010). Assessing the effects of organizational identification on in-role job performance and learning behaviour: The mediating role of learning goal orientation. Personnel Review, 39(2), 242-258.

Dweck, C. S. (2008). Motivational processes affecting learning. American Psychologist, $\quad$ 41(10), 1040-1048.

Esen, E. (2009). Employees organizational engagement. Psychology, 82, 184- 199.

Hakanen, J. J. (2006). Burnout and work engagement among teachers. Journal of School Psychology, 43(7), 495-513.

Schiefele, U., \& Schaffner, E. (2015). Teacher interests, mastery goals, and self-efficacy as predictors instructional practices and student motivation. Contemporary Educational Psychology, 42, 159-171.

Van Yperen, N. W. (2006). A novel approach to assessing achievement goals in the context of the $2 \times 2$ framework: Identifying distinct profiles of individuals with different dominant achievement goals. Personality and Social Psychology Bulletin, 32(11), 1432-1445.

VandeWalle, D. (2004). A goal orientation model of feedback-seeking behavior. Human Review, 13(4), 581-604.

Zhang, M. J., Law, K. S., \& Lin, B. (2016). You think you are big fish in a small pond? overqualification, goal orientations, and proactivity at work. Journal of Behavior, 37(1), 61-84.

Resource Management

Perceived

Organizational 